\title{
Should partially hydrolyzed infant formula be given to the general infant population for the primary prevention of allergic disease?
}

\author{
Tae Won Song, MD, PhD \\ Department of Pediatrics, Inje University Ilsan Paik Hospital, Inje University College of Medicine, Goyang, Korea
}

Peptides must be in the range of $10-70 \mathrm{kD}$ to act as an allergen. Whole cow milk-based formulas contain proteins in the range of $14-67 \mathrm{kD}$. Partially hydrolyzed infant formula (PHF) was developed to reduce protein allergenicity through heat treatment and chemical and enzymatic hydrolysis, resulting in a reduced molecular weight and peptide size. PHF contains shortened oligopeptides that have a molecular weight $<5 \mathrm{kD}$ (range, 3-10 kD), and extensively hydrolyzed infant formula contains peptides with a molecular weight $<3 \mathrm{kD}$.)

Primary prevention involves blocking immunologic sensitization to an allergen. For the primary prevention of allergic disease, studies have focused on high-risk infants with a family history of allergic disease. For all infants, exclusive breastfeeding is recommended for at least the first 4-6 months of life. A Cochrane review published in 2018 presented no evidence that the use of hydrolyzed formula over breastfeeding prevents allergic disease. ${ }^{2)}$ According to current infant feeding guidelines, if breastfeeding is impossible, the use of extensively hydrolyzed infant formula (EHF) is recommended for patients of cow milk allergy, and the use of EHF or PHF can be considered in cases of high-risk infants as a strategy for preventing allergic disease. ${ }^{3,4)}$

However, questionable and negative outcomes with the use of PHF for the prevention of allergic disease have been reported very recently. According to the results of a 15-year followup of the German Infant Nutritional Intervention (GINI) study, a prospective randomized double-blind trial of full-term neonates with atopic heredity in a German birth cohort, PHF failed to show a significant influence on immunoglobulin E sensitization but showed a preventative effect on eczema until adolescence without a rebound phenomenon. ${ }^{5)}$ A systematic review and meta-analysis of studies published between 1946 and 2015 found no consistent evidence to support the current recommendations; rather, it reported evidence of publication bias, methodological bias, and conflicts of interest in those studies reporting allergic outcomes, including the GINI study. ${ }^{6}$ The authors suggested that the current recommendation of using hydrolyzed formula in place of standard cows' milk formula to prevent allergies in high-risk infants be revised. ${ }^{6}$ A Cochrane review published in 2018 also found no evidence to support prolonged feeding of a hydrolyzed compared with standard formula for preventing allergic disease in infants who cannot be exclusively breastfed. ${ }^{2)}$ Another recent meta-analysis showed positive prevention outcomes with PHF from one company, but the majority of included studies were industry-supported. . $^{7}$ A pharmacoeconomic analysis demonstrated that PHF compared with standard formula was cost-effective for high-risk infants for preventing atopic dermatitis and cost-saving compared with extensively hydrolyzed infant formula when used in prevention, but this study was also industry-supported. ${ }^{8)}$

In the current issue of Korean Journal of Pediatrics, Vandenplas et al. ${ }^{1)}$ reviewed the evidence on PHF use for nonbreastfed infants both for the prevention of atopic disease in high-risk infants and as routine starter formula regardless of the allergic risk status and suggested
Corresponding author: Tae Won Song, MD, PhD Department of Pediatrics, Ilsan Paik Hospital, Inje University College of Medicine, 170 Juhwa-ro, Ilsanse0-gu, Goyang 10380, Korea Tel: +82-31-910-7101

Fax: +82-31-910-7108 E-mail: twsong@paik.ac.kr https://orcid.org/0000-0001-6443-5749

Received: 14 March, 2019

Revised: 30 April, 2019

Accepted: 17 May, 2019
Copyright (C) 2019 by The Korean Pediatric Society

This is an open-access article distributed under the terms of the Creative Commons Attribution NonCommercial License (http://creativecommons.org/ licenses/by-nc/4.0/) which permits unrestricted noncommercial use, distribution, and reproduction in any medium, provided the original work is properly cited. 
that the use of PHF for preventing allergic disease should not be limited to high-risk infants, on the basis of three aspects. First, they mentioned in an epidemiological study that half of the infants who will develop an allergy are not in the high-risk group because the not-at-risk group is significantly larger than the high-risk group and that not-at-risk infants have an 15\% genetic risk of developing an allergy. ${ }^{\text {9) }}$ This could be epidemiological evidence for PHF as a routine formula for the general population if the strong recommendation of PHF to high-risk nonbreastfed infants as primary prevention of allergic disease is preceded. However, this seemed doubtful for prevention under recent negative outcomes of PHF, even in high-risk infants. Second, they showed a literature review of studies using PHF in the general population (for which a family history of allergy was neither an inclusion nor an exclusion criterion), which indicated a reduction in atopic manifestations on using a specific PHF compared with standard formula in the first years of life. ${ }^{10)}$ However, numerous limitations to these studies were identified, and this study was also industry-supported. Third, they mentioned that PHF meets all nutritional requirements and supports normal growth. ${ }^{10}$ However, the long-term data of PHF in healthy infants on growth, body composition, hormonal responses, and serum metabolites are limited, although no data suggest that PHF is potentially harmful for healthy term infants.

In conclusion, the use of PHF in high-risk infants as a strategy for preventing allergic disease is still encouraged by current infant feeding guidelines, but some recent studies demonstrated opposite opinions. From this point of view, PHF as a routine starter formula for infants in the general population to prevent allergic disease seems is insufficiently evidenced. Future prospectively registered and independently funded PHF trials are needed.

\section{Conflict of interest}

No potential conflict of interest relevant to this article was reported.

\section{References}

1. Vandenplas Y, Munasir Z, Hegar B, Kumarawati D, Suryawan A, Kadim M, et al. A perspective on partially hydrolyzed protein infant formula in nonexclusively breastfed infants. Korean J Pediatr 2019; 62:149-54.

2. Osborn DA, Sinn JK, Jones LJ. Infant formulas containing hydrolysed protein for prevention of allergic disease. Cochrane Database Syst Rev 2018;10:CD003664.

3. Fleischer DM, Spergel JM, Assa'ad AH, Pongracic JA. Primary prevention of allergic disease through nutritional interventions. J Allergy Clin Immunol Pract 2013;1:29-36.

4. Song TW, Ahn K, Lee SY. Prevention of food allergy in infants: recommendation for infant feeding and complementary food introduction. Allergy Asthma Respir Dis 2015;5:320-5.

5. von Berg A, Filipiak-Pittroff B, Schulz H, Hoffmann U, Link E, Sußmann M, et al. Allergic manifestation 15 years after early intervention with hydrolyzed formulas--the GINI Study. Allergy 2016;71:210-9.

6. Boyle RJ, Ierodiakonou D, Khan T, Chivinge J, Robinson Z, Geoghegan $\mathrm{N}$, et al. Hydrolysed formula and risk of allergic or autoimmune disease: systematic review and meta-analysis. BMJ 2016;352:i974.

7. Szajewska H, Horvath A. A partially hydrolyzed $100 \%$ whey formula and the risk of eczema and any allergy: an updated meta-analysis. World Allergy Organ J 2017;10:27.

8. Spieldenner J, Belli D, Dupont C, Haschke F, Iskedjian M, Nevot Falcó S, et al. Partially hydrolysed 100\% whey-based infant formula and the prevention of atopic dermatitis: comparative pharmacoeconomic analyses. Ann Nutr Metab 2011;59 Suppl 1:44-52.

9. Exl BM, Deland U, Secretin MC, Preysch U, Wall M, Shmerling DH. Improved general health status in an unselected infant population following an allergen-reduced dietary intervention programme: the ZUFF-STUDY-PROGRAMME. Part II: infant growth and health status to age 6 months. ZUg-FrauenFeld. Eur J Nutr 2000;39:145-56.

10. Sauser J, Nutten S, de Groot N, Pecquet S, Simon D, Simon HU, et al. Partially hydrolyzed whey infant formula: literature review on effects on growth and the risk of developing atopic dermatitis in infants from the general population. Int Arch Allergy Immunol 2018;177:123-34. 